DOI: $10.17951 / \operatorname{lrp} .2018 .37 .4 .177-186$

\author{
Celina Kamecka-Antczak \\ Uniwersytet Mikołaja Kopernika w Toruniu \\ https://orcid.org/0000-0001-8476-9738
}

\title{
NIEPEŁNOSPRAWNI = NIEAKTYWNI? PRZYCZYNEK DO DYSKUSJI NAD AKTYWNOŚCIĄ OBYWATELSKĄ OSÓB Z NIEPEŁNOSPRAWNOŚCIĄ INTELEKTUALNĄ
}

\begin{abstract}
Streszczenie: Artykuł dotyczy aktywności obywatelskiej osób z niepełnosprawnością intelektualną. W pracy wykorzystano Kwestionariusz aktywności obywatelskiej Ryszarda Klamuta - narzędzie badawcze autorsko dostosowane do potrzeb i możliwości osób z niepełnosprawnością intelektualną. Badania przeprowadzono wiosną 2018 roku wśród pełnoletnich uczniów toruńskich szkół przysposabiających do pracy z niepełnosprawnością intelektualną w stopniu umiarkowanym. Pozwoliły one na określenie aktywności obywatelskiej badanej grupy, jej średniego wyniku, a także wewnętrznego zróżnicowania. Umożliwiły stwierdzenie, w których kategoriach działania badani uczniowie podejmują największą, a w których najmniejszą aktywność. Badania te są przyczynkiem do pogłębiania zarysowanej problematyki. Wskazano na szereg kolejnych problemów badawczych, dla których rozwiązania można szukać za pomocą zaprezentowanego narzędzia.
\end{abstract}

Słowa kluczowe: niepełnosprawność intelektualna, kompetencje obywatelskie, kompetencje kluczowe, aktywność obywatelska, szkoła przysposabiająca do pracy

\section{WPROWADZENIE}

W 2012 roku jeden z raportów europejskiej sieci informacji o edukacji „Eurydice” poświęcono edukacji obywatelskiej (Edukacja obywatelska w Europie 2012). Od tego momentu wzrosła intensywność dyskusji, badań i rozważań dotyczących kształtowania kompetencji obywatelskich u uczniów. W poszukiwaniach nie znalazło się jednak, jak do tej pory, miejsce na zagadnienia dotyczące rozwijania kompetencji obywatelskich u uczniów z niepełnosprawnością intelektualną. Tymczasem ratyfikowana w 2012 roku Konwencja ONZ o prawach osób niepelnosprawnych zapewnia 
pełne korzystanie ze wszystkich praw człowieka i podstawowych wolności osobom z niepełnosprawnością na równi z innymi obywatelami bez względu na rodzaj oraz stopień niepełnosprawności. Zawarte w konwencji standardy postępowania państwa mają służyć realizacji praw osób z niepełnosprawnością. Spełnienie postanowień konwencji wymaga m.in. dostosowania krajowych legislacji oraz przedsięwzięć natury organizacyjnej i edukacyjnej. Podkreślana w akcie możliwość uczestniczenia w głównym nurcie życia społecznego wiąże się nierozerwalnie z koniecznością rozwijania niezbędnych do tego kompetencji społecznych, w tym obywatelskich.

Podejmowanie aktywności społecznej zależy od oceny własnych możliwości efektywnego funkcjonowania w sytuacjach społecznych, przeświadczenia o możliwości osiągnięcia sukcesu i wiary we własne sprawstwo (Martowska 2012). Dlatego niezwykle istotne jest, by osoby z niepełnosprawnością, a także ich najbliższe środowisko (rodzice, specjaliści, opiekunowie) dostrzegali nie tylko dysfunkcje i ograniczenia wynikające $\mathrm{z}$ uszkodzenia organizmu, ale także indywidualne możliwości i mocne strony każdej jednostki (Baczała, Dąbrowska 2013). W swoich badaniach Ditta Baczała (Baczała 2012; Baczała, Dąbrowska 2013) udowadnia, że „dorosłe osoby z niepełnosprawnością intelektualną są w stanie nabywać kompetencje społeczne pozwalające realizować role społeczne charakterystyczne dla dorosłości. Jest to możliwe przy zgodzie mentalnej społeczeństwa i jego wsparciu" (Baczała, Dąbrowska 2013, s. 16). Tymczasem osoby z niepełnosprawnością intelektualną stanowią grupę szczególnie mocno podlegającą działaniu stereotypów, których powszechność potęguje w nich poczucie odmienności, wyuczoną bezradność, wycofanie i izolację (Ostrowska 2003). Żyjąc często w homogenicznym środowisku, kształtują obraz siebie na podstawie społecznych uprzedzeń, ulegają autostygmatyzacji (Byra 2010). Liczne bariery społeczne ograniczają ich szanse na nabywanie kompetencji społecznych, hamują społeczny rozwój i wyłączają $\mathrm{z}$ możliwości pełnienia różnych ról społecznych.

W najnowszej klasyfikacji zaburzeń psychicznych Diagnostic and Statistical Manual of Mental Disorders DSM-5 (2013) niepełnosprawność intelektualna została uznana za zaburzenie neurorozwojowe. Zdefiniowano ją jako stan, którego symptomy muszą wystąpić w okresie rozwojowym oraz wynikać z poważnych deficytów $w$ funkcjonowaniu adaptacyjnym. Funkcjonowanie adaptacyjne zostało uznane za kluczowe i nadrzędne kryterium w diagnostyce niepełnosprawności intelektualnej. Odnosi się ono do trzech obszarów, które determinują niezależność jednostki i radzenie sobie z codziennymi zadaniami życiowymi. Są to:

- sfera koncepcyjna (zdolności i umiejętności w zakresie języka, czytania, pisania, matematyki, myślenia, wiedzy i pamięci),

- sfera społeczna (funkcjonowanie społeczne, empatia, komunikacja interpersonalna, zdolności do zawierania i podtrzymywania kontaktów społecznych), 
- sfera praktyczna (samodzielność w opiece osobistej, odpowiedzialność w pracy, gospodarowanie pieniędzmi, zarządzanie czasem wolnym, planowanie wykonywania zadań) (Żyta 2014).

Coraz częściej odchodzi się od kategoryzacji ze względu na stopień niepełnosprawności intelektualnej (lekki, umiarkowany, znaczny, głęboki) na rzecz podziału uwzględniającego funkcjonowanie społeczne danej osoby i zakres indywidualnie dobranego wsparcia, jakiego należy jej udzielić, aby miała szansę na pełne uczestnictwo w życiu społecznym (Żyta, Ćwirynkało 2013). Jednocześnie należy podkreślić, że mimo przyznanych przez Amerykańskie Towarzystwo Psychiatryczne kodów klasyfikacji niepełnosprawność intelektualna nie jest ani chorobą, ani zaburzeniem psychicznym, lecz stanem, w którym znajduje się dana osoba i który - jak pisze Baczała (2012) - może ulegać zmianie dzięki prawidłowemu procesowi rehabilitacji psychologicznej, pedagogicznej i społecznej. Odpowiednie warunki stworzone w środowisku zewnętrznym pozwalają przewartościować cechy osobowościowe i temperamentalne, a tym samym wspomóc nabywanie kompetencji społecznych, co wydaje się szczególnie ważne dla osób z niepełnosprawnością intelektualną (Baczała, Dąbrowska 2013).

Kompetencje obywatelskie najogólniej zdefiniować możemy jako umiejętność współpracy z innymi ludźmi na rzecz dobra wspólnego. Pozwalają one na świadomą partycypację obywatelską, ukierunkowują działalność jednostki na rozwój struktury społeczno-politycznej. Dzięki nim człowiek potrafi połączyć działania podejmowane na rzecz wspólnoty z poczuciem własnej autonomii. Wśród umiejętności kluczowych dla rozwoju podmiotu są zarówno współpraca, rozwiązywanie konfliktów, zdolność przedkładania dobra wspólnoty nad dobro indywidualne, jak i krytyczne myślenie oraz dociekliwość (Plecka i in. 2013). Aktywność obywatelska to zaś:

aktywność społeczna jednostek (obywateli), będąca wynikiem indywidualnych motywów lub oddolnych inicjatyw społecznych, nastawiona na realizację interesu społecznego (dobra wspólnego), podejmowana ze świadomością praw i zobowiązań wynikających $\mathrm{z}$ funkcjonowania systemu demokratycznego, w warunkach spełnianych przez tenże system (Klamut 2013, s. 192).

Jest to klasyczne, Arystotelesowskie ujęcie aktywności obywatelskiej, nawiązujące do społecznej natury ludzkiej: zoon politikon - animal sociale. Natura człowieka jako istoty społecznej może w pełni realizować się tylko we wspólnocie. Definicja ta wyraźnie wskazuje, że aktywność obywatelska jest pojęciem szerszym niż aktywność polityczna, odnosząca się tylko do perspektywy władzy. Swoim zakresem obejmuje szeroki wachlarz możliwych działań na rzecz wspólnoty. Może przejawiać się w różnych sposobach działania. Osią podziału rodzajów aktywności obywatelskiej, którą przyjmuje Klamut, są dwa kryteria: 
- obszar zaangażowania - ukierunkowanie aktywności na poprawę jakości życia współobywateli (służba) lub na współtworzenie systemu władzy, zaangażowanie w rządzenie (władza),

- stosunek jednostki do grupy - człowiek podejmuje aktywność indywidualnie (niezależnie od grupy) lub w perspektywie społeczności (zależnie od grupy) jako członek określonej zbiorowości, której jest lub czuje się częścią.

Zgodnie z tym podziałem otrzymujemy swoistą mapę zaangażowania w dbałość o interes społeczny. Jednostka może podejmować jedno lub jednocześnie wiele różnych działań charakterystycznych dla odrębnych kategorii: społecznikostwa, partycypacji społecznej, indywidualnej aktywności politycznej, partycypacji politycznej (Klamut 2013).

Na podstawie omówionego modelu aktywności obywatelskiej Ryszard Klamut stworzył kwestionariusz składający się z 17 twierdzeń pozwalających na pomiar wymienionych czterech kategorii z zastosowaniem pięciostopniowej skali Likerta: od 1 (zdecydowanie nie) do 5 (zdecydowanie tak). Badania towarzyszące tworzeniu oraz pomiarowi właściwości psychometrycznych kwestionariusza KAO opisano w artykule: Kwestionariusz aktywności obywatelskiej (KAO) - narzędzie do badania różnych rodzajów aktywności obywatelskiej (Klamut 2015). Złożona procedura badawcza, w której przeprowadzono trzy badania zasadnicze, umożliwiła wybór 17 spośród proponowanych 44 twierdzeń służących do pomiaru czterech kategorii aktywności obywatelskiej (społecznikostwa, partycypacji społecznej, indywidualnej aktywności politycznej i partycypacji politycznej). Grupa badana każdorazowo składała się 200-300 osób w wieku 19-84 lat pochodzących z różnych regionów Polski, będących studentami studiów stacjonarnych lub niestacjonarnych różnych kierunków oraz osobami niestudiującymi. Analizy psychometryczne wykazały, że stworzony kwestionariusz może być uznany za narzędzie rzetelne i trafne, umożliwiające lepsze poznanie zjawiska aktywności obywatelskiej. Wyniki przedstawionych $\mathrm{w}$ artykule badań nie pozwoliły jednak na pełne zweryfikowanie trafności kwestionariusza. Wskazywały na konieczność sprawdzenia trafności kryterialnej względem osób przynależnych do organizacji politycznej, a także przejścia od weryfikacji ogólnej do weryfikacji dla grup szczegółowych, np. wiekowych lub płciowych, czy właśnie osób z niepełnosprawnością intelektualną. Ze względu na powyższe zastrzeżenia znaczenie będą mieć dalsze badania prowadzone za pomocą kwestionariusza. 


\section{BADANIA WŁASNE}

Długość i prostota kwestionariusza KAO są argumentami przemawiającymi za możliwością zastosowania go do badań aktywności obywatelskiej osób z niepełnosprawnością intelektualną. Narzędzie to pozwala na poszukiwanie odpowiedzi na pytanie, jak kształtuje się mapa aktywności obywatelskiej tej grupy. $\mathrm{Z}$ powodu ograniczonych możliwości, jakie ma jeden badacz, kierując się dostępnością badanych, zredukowałam celowo próbę badawczą do grupy uczniów z niepełnosprawnością intelektualną w stopniu umiarkowanym, którzy uczęszczali do dwóch toruńskich szkół przysposabiających do pracy. Dokonując wyboru, liczyłam na możliwości dalszego prowadzenia badań na reprezentatywnej, dobranej losowo próbie. Postawiłam dwa pytania badawcze:

1. W jakiej kategorii aktywności obywatelskiej modelu Ryszarda Klamuta badani uczniowie uzyskują ogółem najlepsze wyniki?

2. W jakiej kategorii aktywności obywatelskiej modelu Ryszarda Klamuta badani uczniowie uzyskują ogółem najsłabsze wyniki?

Istotnym założeniem organizacji badania, zgodnie z przyjętym paradygmatem emancypacyjnym (por. Krause 2010, Podgórska- Jachnik 2015), było umożliwienie uczniowi jak najbardziej samodzielnego wypełniania kwestionariusza. Zrezygnowano więc z formy odczytywania i wypełniania kwestionariusza przez siedzącego naprzeciwko ucznia na rzecz wspólnego głośnego odczytywania pytań przez badacza i ucznia (siedzących obok siebie) oraz - zależnie od możliwości fizycznych ucznia - samodzielnego zaznaczania odpowiedzi. Spełnienie tego założenia ułatwić miała zmieniona forma graficzna kwestionariusza, dostosowana do potrzeb osób z niepełnosprawnością intelektualną. Zastosowano większą czcionkę oraz interlinię w celu umożliwienia badanemu śledzenia kolejnych pytań. By ułatwić zrozumienie systemu odpowiedzi według pięciostopniowej skali Likerta oraz samodzielne zakreślanie odpowiedzi, pod każdym pytaniem umieszczono poziomą skalę kolorową z przypisanymi odpowiedziom kolorami:

- zdecydowanie nie - intensywnie czerwony,

- nie - bladoczerwony,

- ani tak, ani nie - żółty,

- tak-bladozielony,

- zdecydowanie tak - intensywnie zielony.

Każdy uczeń miał możliwość samodzielnego zaznaczania odpowiedzi na kolorowej skali. Jeśli nie chciał lub nie mógł z niej skorzystać, wówczas po usłyszeniu odpowiedzi ustnej odpowiedni wariant zaznaczał siedzący obok badacz. Jeżeli zachodziła taka konieczność, badacz przypominał uczniowi wyjaśnione na wstępie odpowiedzi zawarte w skali. Wyjaśniał znaczenie niezrozumiałych pojęć. 
Badania właściwe, poprzedzone badaniami pilotażowymi, przeprowadzono w marcu i kwietniu 2018 roku na grupie 18 uczniów z dwóch toruńskich szkół przysposabiających do pracy. Uczestnikami byli pełnoletni uczniowie $\mathrm{z}$ niepełnosprawnością intelektualną $\mathrm{w}$ stopniu umiarkowanym $(10 \mathrm{z}$ jednej szkoły i $8 \mathrm{z}$ drugiej). Badania przeprowadzono podczas indywidualnych spotkań badacza z uczniem. Przed przystąpieniem do badań uczeń uzyskiwał informację o ich celu, proszony był o podpisanie zgody na ich przeprowadzenie oraz anonimowe wykorzystanie zebranych informacji do celów naukowych. Wraz z badaczem wypełniał także metryczkę dla uczniów, podając m.in. swój wiek, płeć, klasę, szkołę. Każdemu respondentowi udzielona została instrukcja dotycząca formy badania, skali odpowiedzi i sposobu odpowiadania.

\section{WYNIKI BADAŃ}

W tabeli 1 (poniżej) zestawiono średnie arytmetyczne uzyskane w badaniu Kwestionariuszem aktywności obywatelskiej (KAO) Ryszarda Klamuta (2015) ogółem i osobno dla każdej z wyodrębnionych przez autora kategorii: społecznikostwa, partycypacji społecznej, indywidualnej aktywności politycznej oraz partycypacji politycznej. Za udzielone odpowiedzi przyznano punkty zgodnie ze skalą, kolejno:

- zdecydowanie nie - 1 punkt,

- nie - 2 punkty,

- ani tak, ani nie - 3 punkty,

- tak-4 punkty,

- zdecydowanie tak - 5 punktów.

Maksymalny możliwy wynik do osiągnięcia dla całości kwestionariusza wynosi 85 punktów (5 punktów x 17 pytań). Kwestionariusz nie ma opracowanych norm pozwalających na porównanie uzyskanych w badaniu wyników do średniej czy też na przyporządkowanie do uzyskanej liczby punktów konkretnego poziomu aktywności. Dla analizy danych zebranych w tabeli 1 jako minimalny próg aktywności przyjęto zatem odpowiedź środkową: ani tak, ani nie. Dlatego liczba punktów wymagana, by uzyskać wynik pozytywny, jest wartością większą lub równą iloczynowi punktów przypisanych odpowiedzi środkowej i liczbie pytań. Dla całości kwestionariusza wynosi 51 punktów (3 punkty x 17 pytań), dla wyodrębnionych kategorii składających się z 4 pytań - 12 punktów (3 punkty x 4 pytania), dla kategorii indywidualnej aktywności politycznej składającej się z 5 pytań - 15 punktów (3 punkty x 5 pytań).

Średnią wyższą lub równą wartości minimalnego wyniku pozytywnego interpretować można zatem jako występowanie aktywności obywatelskiej w grupie 
badanych. Im wyższa jest średnia, tym większa aktywność badanej grupy. Dodatkowo w ostatniej kolumnie tabeli 1 wyliczono odchylenie standardowe dla całego kwestionariusza i poszczególnych jego kategorii, co pozwala zobrazować wewnętrzne przeciętne zróżnicowanie wyników. Im mniejsze jest odchylenie, tym bardziej jednolita wewnętrznie jest badana grupa, a uzyskiwane przez poszczególnych uczniów wyniki sytuują się bliżej średniej. Im większe jest odchylenie, tym grupa badawcza jest bardziej zróżnicowana, a jednostkowe wyniki bardziej oddalone od średniej arytmetycznej (Rubacha 2008).

Tabela 1. Kwestionariusz aktywności obywatelskiej - wyniki badań własnych

\begin{tabular}{|l|c|c|c|c|}
\hline & $\begin{array}{c}\text { Uzyskane wyniki } \\
(\text { średnia } \\
\text { arytmetyczna) }\end{array}$ & $\begin{array}{c}\text { Minimalny } \\
\text { wynik } \\
\text { pozytywny }\end{array}$ & $\begin{array}{c}\text { Maksymalny } \\
\text { możliwy } \\
\text { wynik }\end{array}$ & $\begin{array}{c}\text { Odchylenie } \\
\text { standardowe }\end{array}$ \\
\hline KAO & 46,61 & 51 & 80 & 10 \\
\hline Społecznikostwo & 13,55 & 12 & 20 & 4 \\
\hline Partycypacja społeczna & 11,44 & 12 & 20 & 6 \\
\hline $\begin{array}{l}\text { Indywidualna } \\
\text { aktywność polityczna }\end{array}$ & 15,55 & 15 & 25 & 1,5 \\
\hline Partycypacja polityczna & 5,22 & 12 & 20 & 4 \\
\hline
\end{tabular}

Źródło: opracowanie własne.

\section{DYSKUSJA WYNIKÓW}

Badani uczniowie uzyskali ogółem najlepsze wyniki w kategorii społecznikostwa. Zdobyli średnio 13,55 punktu, czyli o 1,55 punktu więcej od minimalnej pozytywnej liczby punktów wymaganych do stwierdzenia aktywności, oraz 8,56 punktu mniej od możliwego wyniku maksymalnego. Ogółem najsłabsze wyniki uczniowie uzyskali w kategorii partycypacji politycznej. Średnio 5,22 punktu to wynik o 6,78 punktu poniżej minimalnej wymaganej liczby. Partycypacja polityczna okazała się także kategorią o najniższym odchyleniu standardowym - znaczy to, że zróżnicowanie odpowiedzi udzielanych przez uczniów w tej kategorii było bardzo małe: nie padła żadna odpowiedź twierdząca (tak ani $z$ decydowanie tak). Faktycznie żaden uczeń objęty badaniem nie prowadził w tym czasie ani wcześniej aktywności o charakterze politycznym. Trzech uczniów zaznaczyło odpowiedź ani tak, ani nie. Wszyscy wybór tego wariantu argumentowali w podobny sposób, pozwalający badaczowi wnioskować, że organizacja polityczna nie jest sposobem angażowania się tych uczniów, ale chcieliby oni mieć możliwość tego typu aktywności. Ci sami uczniowie, którzy w badaniu partycypacji politycznej wybrali odpowie- 
dzi środkowe, uzyskali wysokie wyniki w kategorii indywidualnej aktywności politycznej.

Ogólny średni wynik dla KAO (46,61 punktu) sytuuje się nieznacznie (o 4,39 punktu) poniżej minimalnego wyniku wymaganego dla stwierdzenia aktywności. Poza kategorią społecznikostwa nieznacznie powyżej minimalnego wymaganego wyniku pozytywnego jest także średnia wyników dla indywidualnej aktywności politycznej. Kategoria ta charakteryzuje się najwyższym odchyleniem standardowym. Świadczy to o dużym zróżnicowaniu odpowiedzi na pytania z tego zakresu. Dla kategorii indywidualnej aktywności politycznej uczniowie rzadko wybierali środkowy wariant odpowiedzi (ani tak, ani nie), dzielili się raczej na uczniów aktywnych i zdecydowanie aktywnych oraz świadomie i zdecydowanie biernych. Uczniowie wybierający odpowiedzi skrajne zdawali się wykazywać największą świadomością w podejmowaniu wyborów - interesowali się sprawami politycznymi lub świadomie przyjmowali postawę bierną ${ }^{1}$.

\section{PODSUMOWANIE}

W Kwestionariuszu aktywności obywatelskiej Ryszarda Klamuta (2015) nie ma opracowanych norm, dzięki którym można by ocenić, jak wyniki wypadają na tle większej populacji zarówno reprezentatywnej próby uczniów z niepełnosprawnością intelektualną, jak i uczniów szkół ponadpodstawowych w normie intelektualnej. Ponadto biorąc pod uwagę specyfikę środowiska szkolnego i deklarowane aktywności obywatelskie badanych uczniów, ale nie znając ich komptencji społecznych i obywatelskich, należy postawić pytanie o dalsze losy absolwentów. W tym kontekście szczególnie interesująca jest umiejętność podtrzymania i zwiększenia inicjowanych w szkole aktywności, faktycznego społecznego włączania się w nie. Jednocześnie małe rozmiary kwestionariusza KAO oraz jasne i proste sformułowanie twierdzeń pozwalają prowadzić badania wielu zmiennych - uwarunkowań badanej aktywności obywatelskiej. Na bazie powyższych refleksji postawić można szereg kolejnych pytań badawczych, na które warto poszukać odpowiedzi:

1. Jak wyniki KAO uzyskane przez uczniów szkół przysposabiających do pracy wypadają w stosunku do wyników uzyskanych przez uczniów w normie intelektualnej?

${ }^{1}$ Elementy badania jakościowego w postaci spontanicznych komentarzy uczniów do udzielanych odpowiedzi nie były planowaną częścią badania. Odegrały jednak istotną rolę w weryfikacji, czy respondenci rozumieją treść zadawanych pytań. Pozwoliły także badaczowi lepiej poznać motywacje uczniów do podejmowania aktywności obywatelskiej oraz czynniki tej aktywności sprzyjające. 
2. Jak kształtują się wyniki KAO dla próby reprezentatywnej młodych dorosłych z niepełnosprawnością intelektualną w stopniu umiarkowanym?

3. Czy organizacja przestrzeni szkoły przysposabiającej do pracy różnicuje wyniki KAO uzyskiwane przez uczniów? Jeśli tak, to w których wariantach?

4. Jaka zależność zachodzi między poziomem aktywności obywatelskiej (KAO) a posiadanymi kompetencjami społecznymi/obywatelskimi?

5. Jaka jest zależność między doświadczaniem społeczno-kulturowych barier inkluzji a aktywnością obywatelską uczniów z umiarkowanym stopniem niepełnosprawności intelektualnej toruńskich szkół przysposabiających do pracy?

\section{LITERATURA}

Baczała D., Dąbrowska K., 2003, Kompetencje społeczne osób dorostych z niepełnosprawnościq intelektualna. W: D. Baczała, J.K. Błeszyński (red.), Rozwój społeczny osób $z$ niepełnosprawnością intelektualną. Ograniczenia i możliwości w zakresie kompetencji społecznych. Toruń, Wydawnictwo Adam Marszałek.

Baczała D., 2012, Niepełnosprawność intelektualna a kompetencje społeczne. Toruń, Wydawnictwo UMK.

Byra S., 2010, Mechanizmy kształtowania się stereotypów dotyczacych osób z niepełnosprawnością. W: M. Chodkowska (red.), Stereotypy niepelnosprawności. Między wykluczeniem a integracja. Lublin, Wydawnictwo UMCS.

Edukacja obywatelska w Europie, 2012. Bruksela, Eurydice, opublikowano: https:// eurydice.org.pl/wpcontent/uploads/2014/11/citizen_PL.pdf [dostęp: 19.02.2019].

Kamecka-Antczak C., 2018, Aktywność obywatelska osób z niepetnosprawnościa intelektualna. Spoteczno-kulturowe bariery inkluzji. Niepublikowana praca magisterska.

Klamut R., 2013, Aktywność obywatelska jako rodzaj aktywności społecznej-perspektywa psychologiczna. „Studia Socjologiczne” 1/208, 187-203.

Klamut R., 2015, Kwestionariusz aktywności obywatelskiej (KAO) - narzędzie do badania różnych rodzajów aktywności obywatelskiej. „Psychologia Społeczna”, t. 10 (32), 68-83.

Konwencja ONZ o prawach osób niepetnosprawnych, 2012. Dz.U., poz. 1169.

Martowska K., 2012, Psychologiczne uwarunkowania kompetencji społecznych, opublikowano: http://www.liberilibri.pl/martowska/item/download/16_9f7a874bd4b9 b427988c7ea8ecfee563 [dostęp: 17.06.2017].

Ostrowska A., 2003, Kompetencje społeczne osób niepelnosprawnych - bariery dorostości. W: A. Kobylańska, K.D. Rzedzicka (red.), Dorosłość, niepetnosprawność, czas współczesny. Kraków, Oficyna Wydawnicza Impuls. 
Plecka D., Turska-Kawa A., Wojtasik W., 2013, Obywatelskie kompetencje polityczne. „Kultura i Edukacja” 3(96), 73-94.

Rubacha K., 2008, Metodologia badań nad edukacja. Warszawa, WAiP.

Zalecenie Parlamentu Europejskiego i Rady 2006/962/WE z dnia 18 grudnia 2006 r. $w$ sprawie kompetencji kluczowych w procesie uczenia się przez całe życie. Dz.U., L 394/10 [pozyskano z: http://eur-lex.europa.eu].

Żyta A., 2014, Niepełnosprawność intelektualna - najnowsze zmiany terminologiczne i diagnostyczne $w$ świetle DSM-5, ICD-11 oraz AAIDD. „Niepełnosprawność i Rehabilitacja", nr 1. Warszawa, IRSS.

Żyta A., Ćwirykało K., 2013, Nowe tendencje i kierunki rozwoju pedagogiki osób z niepełnosprawnością intelektualną: zmiany terminologiczne. „Niepełnosprawność,, nr $10,52-61 / 2013,52-61$.

\author{
DISABLED = INACTIVE? \\ A CONTRIBUTION TO THE DISCUSSION ON CIVIC ACTIVITY \\ OF PEOPLE WITH INTELLECTUAL DISABILITY
}

\begin{abstract}
This article concerns civic activity of people with intellectual disabilities. The work involved a ready-made research tool: the Civic Activity Questionnaire by Ryszard Klamut. This tool has been individually adapted to the needs and capabilities of people with intellectual disabilities. The research was carried out in the spring of 2018 among adult students of special vocational training schools in Torun with moderate intellectual disability. The research has shown the possibility of using a simple universal tool after prior adaptation to study people with intellectual disabilities. They allowed to determine the civic activity of the studied group, its average result, as well as internal differentiation. It was shown in which activity categories the examined students take the most and in which the least activity. The presented research gives the opportunity to deepen the outlined problems. A number of subsequent research problems were pointed out. Solutions to them can be found using the presented tool.
\end{abstract}

Keywords: intellectual disability, civic competences, key competences, civic activity, special vocational training school 